\title{
Dream Anxiety in Hemodialysis and Peritoneal Dialysis Patients
}

\author{
Sultan Ozkurt', Ece Yazla ${ }^{2}$, Ahmet Musmul ${ }^{3}$ \\ 'Department of Nephrology, Faculty of Medicine, Eskisehir Osmangazi University, Eskisehir \\ ${ }^{2}$ Department of Psychiatry, Hitit University, Çorum \\ ${ }^{3}$ Department of Biostatistics, Faculty of Medicine, Eskisehir Osmangazi University, Eskisehir
}

\begin{abstract}
Summary
Abstract

Introduction: Sleep disorders are frequently reported in hemodialysis and peritoneal dialysis patients, but there are no studies investigating the dreams of these patients. This study was an examination of differences in the level of dream anxiety between hemodialysis patients and peritoneal dialysis patients. A comparison of depression and anxiety symptoms, sleep quality, and sleepiness between these 2 groups was also performed.

Methods: In this observational, cross-sectional study, 49 hemodialysis patients and 29 peritoneal dialysis patients treated at an outpatient nephrology clinic were enrolled. A sociodemographic data collection form, the Van Dream Anxiety Scale, the Pittsburgh Sleep Quality Index, the Insomnia Severity Index, and the Beck Depression and Anxiety Inventories were administered, and hemoglobin level and fractional clearance of body water by dialysis (Kt/N urea) were measured.

Results: There were no significant differences between the groups in terms of dream anxiety $(p=0.517)$, depression ( $p=0.889)$, sleep quality $(p=0.221)$, insomnia severity $(p=0.152)$ or hemoglobin level $(p=0.505)$.

Discussion and Conclusion: We did not find any significant difference in the level of depression, anxiety, sleep quality, or insomnia severity between hemodialysis and peritoneal dialysis patients in our study. Similarly, the level of dream anxiety was consistent with these findings.

Keywords: Dream anxiety; hemodialysis; peritoneal dialysis.
\end{abstract}

Correspondence (iletişim): Sultan Ozkurt, M.D. Department of Nephrology, Faculty of Medicine, Eskisehir Osmangazi University, Eskisehir, Turkey Phone (Telefon): +90 22223929 79-23 09 E-mail (E-posta): dr.s.guvenir@hotmail.com

Submitted Date (Başvuru Tarihi): 03.08.2017 Accepted Date(Kabul Tarihi): 12.09.2017

Copyright 2017 SBÜ Haydarpaşa Numune Eğitim ve Araştırma Hastanesi | Bu CC BY-NC lisansı altında açık erişimli bir makaledir.

This is an open access article under the CC BY-NC license (http://creativecommons.org/licenses/by-nc/4.0/). 


\title{
Hemodiyaliz ve Periton Diyalizi Hastalarında Rüya Bunaltısı
}

\begin{abstract}
Giriş ve Amaç: Hemodiyaliz ve periton diyalizi hastalarında uyku bozuklukları sıkça rapor edilmekte olup, bu hastaların rüyalarını araştıran çalışma bulunmamaktadır. Biz hemodiyaliz ve periton diyalizi hastalarında rüya bunaltısı düzeyindeki farklılıkları araştırmayı planladık. Bu iki grup arasında depresyon ve anksiyete semptomları,uyku kalitesi ve uykusuzluk düzeylerini de karşılaştırmayı planladık.

Yöntem ve Gereçler: Bu gözlemsel kesitsel çalışmaya nefroloji kliniğinde ayaktan takip edilen 49 hemodiyaliz hastası ve 29 peritoneal diyaliz hastası alındı. Gerekli özelliklerin değerlendirilmesi için Sosyodemografik Veri Toplama Formu, Van Rüya Bunaltısı Ölçeği (VDAS), Pittsburg Uyku Kalitesi İndeksi (PSQI), Uykusuzluk Şiddet İndeksi (ISI), Beck Depresyon ve Anksiyete Envanteri kullanıldı. Hemoglobin ( $\mathrm{Hb}), \mathrm{Kt} / \mathrm{V}$ üre indeksi ölçüldü.

Bulgular: Rüya bunaltısı ( $p=0.517)$, depresyon $(p=0,889)$, uyku kalitesi $(p=0,221)$, uykusuzluk şiddeti $(p=0,152)$ ve hb $(p=0,505)$ açısından gruplar arasında anlamlı farklılık yoktu.

Tartışma ve Sonuç: Çalışmamızda hemodiyaliz ve periton diyalizi hastaları arasında depreyon, anksiyete, uyku kalitesi ve uykusuzluk şiddeti düzeyleri açılarından anlamlı fark bulmadık. Benzer şekilde rüya bunaltısı düzeyi de bu bulgularla tutarlı bulundu.
\end{abstract}

Anahtar sözcükler: Hemodiyaliz; periton diyalizi; rüya bunaltısı.

lnem n many chronic diseases, including chronic kidney disease, sleep disorders are frequently detected and sleep quality is impaired ${ }^{[1]}$. Sleep quality has been shown to be poor in patients undergoing hemodialysis or peritoneal dialysis ${ }^{[2]}$. As a result of a study on sleep disorders in hemodialysis patients, it has been said that in patients with end-stage renal insufficiency, sleep disorders may be associated with more complicated events than bodily accumulation of waste materials ${ }^{[3]}$. Similarly, in another study investigating sleep quality in hemodialysis patients, sleep quality was found to be impaired despite the adequacy of dialysis ${ }^{[4]}$. When sleep quality was investigated in patients with peritoneal dialysis, they were, likewise, found to have poor sleep quality ${ }^{[5]}$. When both dialysis modalities were compared in terms of sleep disorders, although there were differences between dialysis subgroups in terms of different sleep disorders, insomnia was common in both groups ${ }^{[6]}$. Insomnia symptoms in patients with chronic renal failure interfere with their quality of life ${ }^{[7]}$.

Mood disorders have been established as one of the determinative factors of sleep quality in dialysis patients ${ }^{[2]}$. The coexistence and association of depression and sleep disorders is widely reported in hemodialysis patients ${ }^{[8]}$. Certain factors are thought to underpin the development of depression and anxiety as well as the deterioration of existing conditions in patients with end-stage renal failure. Among these factors, some of those reported included certain symptoms that emerge due to renal failure, adherence to a dialysis schedule and diet, hospitalizations, fear of disability, and shortened lifespan ${ }^{[9]}$.

Dreams are defined as mental activity occurring during sleep that produces live sensorimotor imaginings experienced as if the person were awake. Emotional content, which may vary greatly and include strong sentiments of fear, anger, happiness, guilt, shame, and so on, may occasionally be severe enough to wake the dreaming individual [10]. The close relationship between dreams and sleep physiology has demonstrated that sleep disorders can cause changes in the content and remembrance of dreams. Different models have been proposed to understand this relationship [11]. When patients with sleep disorders are assessed within the scope of these models, it has been suggested that the stress level of the patients and their discomfort arising from sleep disorders may be reflected in their dreams as negative emotional content ${ }^{[11]}$.

Considering the literature on sleep disorders, and the high anxiety and depression levels in patients with end-stage renal failure, it was assumed that these findings might also be reflected as negative emotional content in patients' dreams. Therefore, the aim of this study was to compare the dream anxiety level of patients who underwent hemodialysis and peritoneal dialysis. Sleep quality, insomnia, and the depression and anxiety levels in both groups were examined.

\section{Materials and Methods}

The study was carried out from May to June of 2017 at the Eskişehir Osmangazi University Faculty of Medicine Nephrology Clinic and the Hitit University Faculty of Medicine Psychiatry Clinic. A total of 29 peritoneal dialysis patients and 49 hemodialysis patients were included in the study. Dialysis participants were selected from patients who had been on dialysis treatment for at least 1 year.

In the hemodialysis patients, the etiological cause was diabetes mellitus in 17 patients, hypertension in 15 patients, chronic glomerulonephritis in 5 patients, polycystic kidney disease in 2 patients, Amyloid A amyloidosis in 1 patient, and unknown cause in 9 patients. The hemodialysis patients 
had been given standard bicarbonate hemodialysis treatment 3 days a week for 4 hours.

In the peritoneal dialysis patients, the etiological cause was diabetes mellitus in 10 patients, hypertension in 7 patients, chronic glomerulonephritis in 3 patients, renal stone disease in 1 patient, and unknown etiology in 8 patients. All of the patients with peritoneal dialysis had been on continuous ambulatory peritoneal dialysis treatment, alternating 4 times a day.

Hemoglobin values and Kt/V urea indices, which are indicators of dialysis adequacy, of patients were recorded. The Kt/ $\mathrm{V}$ urea index was accepted as a marker of inadequate dialysis when it was below 1.2 for hemodialysis patients and below 1.7 for peritoneal dialysis patients.

Before beginning the study, approval was obtained from the ethics committee of Eskişehir Osmangazi University Faculty of Medicine. All of the patients who agreed to participate in the study were provided with the opportunity to read and subsequently signed an informed consent form. Participants first provided sociodemographic information in a form prepared by clinicians. Afterward, the Van Dream Anxiety Scale, the Pittsburgh Sleep Quality Scale, the Insomnia Severity Scale, the Beck Anxiety Scale, and the Beck Depression Scale were administered to participants.

Inclusion criteria for the study were age between 18 and 75 years, no presence of illness that would interfere with giving informed consent, volunteering to participate in the study and signing the informed consent form, no psychiatric or neurological illness that can be detected by medical evaluation and not being in regular treatment due to such a diagnosis, and not having been diagnosed with any psychiatric disorder or narcolepsy in the past. Patients who were clinically unstable due to congestive heart failure, liver cirrhosis, severe chronic obstructive pulmonary disease, infection, malignancy, or severe anemia were also excluded from the study. In addition, smokers and alcohol drinkers were also excluded.

\section{Van Dream Anxiety Scale}

The scale was developed by Agargün et al. ${ }^{[12]}$. Validity and reliability studies have been performed with patients suffering from nightmare disorder. It assesses the level of dream anxiety within the past month. The scale is composed of 17 items with a total score ranging from 0 to 52 . As this scale is the first and only scale for the assessment of dream anxiety, its use in the present study was considered to be appropriate.

\section{Pittsburgh Sleep Quality Index}

Buysse et al. developed this scale ${ }^{[13]}$. Validity and reliability studies of the Turkish version were conducted by Agargün et al. ${ }^{[14]}$. It is a self-assessment scale that was designed to differentiate the individuals with a sleep disorder, identify the sleeping problem, and determine sleep quality. The scale includes 24 items in total; however, only 19 self-reported items are included in the calculation of the scale score, which ranges from 0 to 21 . A score of 5 or greater indicates poor sleep quality.

\section{Insomnia Severity Index}

The scale was created by Bastien et al. ${ }^{[15]}$. Boysan and colleagues authenticated the Turkish version with validity and reliability studies ${ }^{[16]}$. The scale was devised with the objective of evaluating the severity of insomnia symptoms. A total of 7 items that can produce a total score ranging from 0 to 28 make up the assessment. The developers of the scale have stated that a score of 10 points suggests a clinical diagnosis of insomnia and a score over 15 points indicates a definite diagnosis of insomnia.

\section{Beck Depression Inventory}

This inventory was created by Beck et al. ${ }^{[17]}$, and validity and reliability studies of the Turkish version were performed by Hili et al. ${ }^{[18,19]}$. It is used to determine the risk of depression, and to measure the level and change in the severity of depressive symptoms. This self-reported scale is scored for 21 questions. Each item is scored from 0 to 3, with a maximum possible score of 63. A higher total score indicates greater severity of depression. The inventory can be used for individuals aged 15 years or over. The cut-off point for the inventory was reported as 17 in validity and reliability studies of the Turkish version.

\section{Beck Anxiety Inventory}

This instrument was also developed by Beck with other colleagues ${ }^{[20]}$. Validity and reliability of the Turkish version was confirmed by Ulusoy et al. ${ }^{[21]}$. The self-reported inventory is used to quantify the level and change in intensity of anxiety symptoms. The scale comprises 21 questions that result in a total score of 0 to 63 points. A score under 17 indicates a low level of anxiety. The inventory can be used for individuals aged 15 years or more.

\section{Statistical Analysis}

Continuous quantitative variables were presented as $\mathrm{n}$, mean, and standard deviation; qualitative variables were presented 
as $\mathrm{n}$, median, and 25th and 75th percentiles. The Mann-Whitney Rank Sum Test was used for the data that consisted of independent measurements but did not show a normal distribution. Chi-square tests were applied to categorical data sets. Probability value of $p<0.05$ was considered significant. All data analyses were done using IBM SPSS Statistics for Windows, Version 21.0 (IBM Corp., Armonk, NY, USA).

\section{Results}

The mean age of the peritoneal dialysis patients with was $47.79 \pm 11.12$ years and the mean age of the hemodialysis patients was $45.27 \pm 12.66$ years. There was no significant difference between the groups in terms of age $(p=0.414)$. The hemoglobin value of the hemodialysis patients, on average, was $11.07 \pm 1.25 \mathrm{~g} / \mathrm{dL}$, and $11.20 \pm 1.31 \mathrm{~g} / \mathrm{dL}$ in patients with peritoneal dialysis, with no significant difference between groups $(\mathrm{p}=0.505)$. The $\mathrm{Kt} / \mathrm{V}$ value, indicating dialysis adequacy, was $1.47 \pm 0.04$ in hemodialysis patients and $1.77 \pm 0.04$ in peritoneal dialysis patients.

The female to male ratio in the peritoneal dialysis patients was $17 / 15$, and it was $24 / 22$ in the hemodialysis patients; thus, there was no significant difference between groups in terms of gender ( $>0.05$ ). Furthermore, no significant differences between the groups were found in terms of marital status $(p=0.137)$, educational status $(p=0.076)$, or vocational status $(p=0.174)$, as shown in Table 1.

Finally, there was no significant difference between groups in terms of total scores of the Van Sleep Anxiety Scale $(p=0.517)$, the Pittsburgh Sleep Quality Index $(p=0.221)$, the Insom- nia Severity Index $(p=0.152)$, the Beck Depression Inventory $(p=0.889)$, or the Beck Anxiety Inventory, as demonstrated in Table 2.

\section{Discussion}

Regardless of taking regular dialysis treatment, patients with end-stage renal disease have been shown to have frequent sleep disturbances and sleep disorder levels are associated with parameters such as hemoglobin, albumin, and creatinine clearance ${ }^{[1]}$. The available literature stresses the cause of sleep disorders in patients with end-stage renal disease is more complicated than just the accumulation of metabolic waste in the body as well as providing various data on its likely association with inflammation and on the role of low melatonin levels, which all needs to be further clarified. It is clear, on the other hand, that sleep disorders are more frequently observed in these patients than in the healthy individuals [3$22,23]$. Studies, in which sleep qualities of patients undergoing peritoneal dialysis and hemodialysis were separately studied, showed that sleep quality was low in both groups ${ }^{[5,8]}$. When these two groups were compared, there was no difference in sleep hygiene or excessive daytime sleepiness, but insomnia levels were found to be high in both groups ${ }^{[6]}$. In our study, we compared hemodialysis and peritoneal dialysis patients in terms of sleep quality and insomnia severity. We found no significant difference between these two groups. Our results are concordant with those of Losso et al. [6].

People with chronic kidney disease are known to demonstrate a high rate of depression symptoms ${ }^{[24,25]}$. Certain biological, psychological, and social risk factors associated with chronic

\section{Table 1. Sociodemographic characteristics}

\begin{tabular}{|c|c|c|c|c|}
\hline & & $\begin{array}{c}\text { Peritoneal dialysis } \\
\text { n (\%) }\end{array}$ & $\begin{array}{c}\text { Hemodialysis } \\
\text { n (\%) }\end{array}$ & $\mathbf{p}$ \\
\hline \multirow{2}{*}{ Gender } & Male & $15(46.90)$ & $22(47.80)$ & \multirow{2}{*}{$>0.05$} \\
\hline & Female & $17(53.10)$ & $24(52.20)$ & \\
\hline \multirow{4}{*}{ Marital status } & Single & $3(9.40)$ & $8(17.40)$ & \multirow{4}{*}{0.137} \\
\hline & Married & $25(78.10)$ & $35(76.10)$ & \\
\hline & Widowed & $4(12.50)$ & $1(2.20)$ & \\
\hline & Divorced & $0(0.00)$ & $2(4.30)$ & \\
\hline \multirow{4}{*}{ Education } & Literate & $5(15.60)$ & $10(21.70)$ & \multirow{4}{*}{0.076} \\
\hline & Elementary scool & $21(65.60)$ & $30(65.20)$ & \\
\hline & High school & $2(6.30)$ & $6(13.00)$ & \\
\hline & Higher education & $4(12.50)$ & $0(0.00)$ & \\
\hline \multirow{4}{*}{ Profession } & Unemployed & $23(71.90)$ & $23(50.00)$ & \multirow{4}{*}{0.147} \\
\hline & Civil servant & $3(9.40)$ & $3(6.50)$ & \\
\hline & Self-occupied & $4(12.50)$ & $16(34.80)$ & \\
\hline & Retired & $2(6.30)$ & $4(8.70)$ & \\
\hline
\end{tabular}

Chi-Square Tests. 
kidney disease are held responsible for the high rate of depression symptoms ${ }^{[26]}$. In a study investigating depression and anxiety levels in hemodialysis patients, depression and anxiety disorder were identified as important comorbid conditions in patients with end-stage renal failure, and depression and anxiety symptom levels were found to be interrelated [27]. The anxiety disorders in the specified group of patients were associated with depression, low quality of life, and low behavioral adjustment ${ }^{[28]}$. Insomnia levels in a group of patients with chronic renal disease undergoing hemodialysis and peritoneal dialysis were also found to be associated with depression and anxiety levels ${ }^{[7]}$. In our study, we did not find any significant difference between depression or anxiety levels between hemodialysis and peritoneal dialysis patients. The fact that we did not find any significant difference in terms of depression or anxiety levels between hemodialysis and peritoneal dialysis groups is in concordance with the results of Losso et al. ${ }^{[6]}$. However, relatively lower anxiety and depression scores in our dialysis patients might be explained, on contrary to the said study, by exclusion in our study of the patients who have severe comorbidities (such as cancer, congestive heart failure, liver cirrhosis, obstructive pulmonary disease), in addition to the exclusion of antidepressants and anxiolytics receivers, smokers and alcohol drinkers.

There has been no studies in the literature, by now, related to the dreams of patients who undergo dialysis treatment, and our study is important because it is the first study which eval- uates the contents of dreams in dialysis patients. It is anticipated that the stress levels of people with sleep disorder and the discomforts caused by sleep disorders may be reflected in their dreams as negative emotional content ${ }^{[11]}$. In this case, it is expectable that dialysis patients, who are known to have a high prevalence of sleep disorders, depression and anxiety would be reported to have dreams with negative emotional content. In our study, there was no detectable significant difference between hemodialysis and peritoneal dialysis groups in terms of depression, anxiety, sleep quality or insomnia severity levels, and in turn, no difference between the groups in terms of negative emotional content to be reflected in the dreams.

Inadequate dialysis is associated with sleep disorders, and in their study on peritoneal dialysis patients, Liakopoulos et al. demonstrated that insomnia rates which were higher in patients with inadequate dialysis could be reduced by increasing the dialysis dose ${ }^{[29]}$. Based on the Kt / V values, dialysis adequacy was maintained in our patient group. Adequate dialysis may have reduced the frequency of sleep disorders and, consequently, dream anxiety.

In conclusion, we did not find any significant difference in the levels of depression, anxiety, sleep quality, or insomnia severity levels between hemodialysis and peritoneal dialysis patients in our study. Similarly, the level of dream anxiety was consistent with these findings. We believe that, in the future, studies performed with more patients and eliminated limita-

\begin{tabular}{|c|c|c|c|c|c|}
\hline & & $\mathbf{n}$ & Mean \pm SD & $50(25-75)$ & $\mathbf{P}$ \\
\hline \multirow{2}{*}{ Age (years) } & Peritoneal dialysis & 29 & $47.79 \pm 11.12$ & $50.00(37.00-54.50)$ & \multirow{2}{*}{0.414} \\
\hline & Hemodialysis & 49 & $45.27 \pm 12.66$ & $47.00(34.50-55.00)$ & \\
\hline \multirow{2}{*}{ Hemoglobin (g/dL) } & Peritoneal dialysis & 29 & $11.20 \pm 1.31$ & $11.40(10.80-11.95)$ & \multirow{2}{*}{0.505} \\
\hline & Hemodialysis & 49 & $11.07 \pm 1.25$ & $11.20(10.35-11.95)$ & \\
\hline \multirow{2}{*}{$\mathrm{Kt} / \mathrm{V}$} & Peritoneal dialysis & 29 & $1.77 \pm 0.04$ & $1.77(1.75-1.80)$ & \multirow{2}{*}{-} \\
\hline & Hemodialysis & 49 & $1.47 \pm 0.04$ & $1.48(1.45-1.50)$ & \\
\hline \multirow[b]{2}{*}{ VDAS } & Peritoneal dialysis & 29 & $5.24 \pm 8.82$ & $1.00(0.00-7.50)$ & \multirow{2}{*}{0.517} \\
\hline & Hemodialysis & 49 & $4.14 \pm 6.70$ & $0.00(0.00-6.00)$ & \\
\hline \multirow[b]{2}{*}{ BeckAS } & Peritoneal dialysis & 29 & $9.31 \pm 8.31$ & $9.00(3.00-12.50)$ & \multirow[b]{2}{*}{0.893} \\
\hline & Hemodialysis & 49 & $9.63 \pm 8.87$ & $7.00(4.00-13.00)$ & \\
\hline \multirow{2}{*}{ BeckDS } & Peritoneal dialysis & 29 & $12.03 \pm 9.11$ & $11.00(5.50-16.00)$ & \multirow{2}{*}{0.889} \\
\hline & Hemodialysis & 49 & $12.24 \pm 8.88$ & $10.00(5.50-16.50)$ & \\
\hline \multirow{2}{*}{ PittsburghSQI } & Peritoneal dialysis & 29 & $4.83 \pm 3.67$ & $4.00(2.00-6.50)$ & \multirow{2}{*}{0.221} \\
\hline & Hemodialysis & 49 & $5.69 \pm 3.68$ & $5.00(3.00-8.00)$ & \\
\hline \multirow{2}{*}{ Insomnia severity } & Peritoneal dialysis & 29 & $4.55 \pm 6.16$ & $2.00(1.00-5.00)$ & \multirow{2}{*}{0.152} \\
\hline & Hemodialysis & 49 & $5.06 \pm 4.46$ & $4.00(1.00-7.00)$ & \\
\hline
\end{tabular}

VDAS: Van Dream Anxiety Scale; Beck AS: Beck Anxiety Scale; BeckDS: Beck Depression Scale; PittsburghSQI: Pittsburgh Sleep Quality Index Mann-Whitney Rank Sum Test, Median (25\%-75\%). 
tions will draw attention to the sleep disorders and psychological distresses of dialysis patients and will contribute to the delivery of solutions.

Ethics Committee Approval: Before beginning the study, approval was obtained from the Ethics Committee of Eskişehir Osmangazi University Faculty of Medicine.

Peer-review: Externally peer-reviewed.

Authorship Contributions: Concept: S.O., E.Y.; Design: S.O., E.Y.; Data Collection or Processing: S.O, E.Y.; Analysis or Interpretation: A.M.; Literature Search: S.O., E.Y.; Writing: S.O,E.Y.

Conflict of Interest: None declared.

\section{References}

1. Ezzat $H$, Mohab A. Prevalence of sleep disorders among ESRD patients. Ren Fail 2015;37:1013-9. [CrossRef]

2. Masoumi M, Naini AE, Aghaghazvini R, Amra B, Gholamrezaei A. Sleep quality in patients on maintenance hemodialysis and peritoneal dialysis. Int J Prev Med 2013;4:165-72.

3. Abassi MR, Safavi A, Haghverdi M, Saedi B. Sleep Disorders in ESRD Patients Undergoing Hemodialysis. Acta Med Iran 2016;54:176-84.

4. Tosun N, Kalender N, Cinar FI, Bagcivan G, Yenicesu M, Dikici D, et al. Relationship between dialysis adequacy and sleep quality in haemodialysis patients. J Clin Nurs 2015;24:2936-44. [CrossRef]

5. Lai X, Chen W, Bian X, Wang T, Li J, Wang H, et al. Predictors of poor sleep quality and excessive daytime sleepiness in peritoneal dialysis patients. Ren Fail 2015;37:61-5. [CrossRef]

6. Losso RL, Minhoto GR, Riella MC. Sleep disorders in patients with end-stage renal disease undergoing dialysis: comparison between hemodialysis, continuous ambulatory peritoneal dialysis and automated peritoneal dialysis. Int Urol Nephrol 2015;47:369-75. [CrossRef]

7. Theofilou P. Association of insomnia symptoms with kidney disease quality of life reported by patients on maintenance dialysis. Psychol Health Med 2013;18:70-8. [CrossRef]

8. Trbojević-Stanković J, Stojimirović B, Bukumirić Z, Hadzibulić $\mathrm{E}$, Andrić B, Djordjević $\mathrm{V}$, et al. Depression and quality of sleep in maintenance hemodialysis patients. Srp Arh Celok Lek 2014;142:437-43. [CrossRef]

9. Feroze U, Noori N, Kovesdy CP, Molnar MZ, Martin DJ, Reina-Patton A, et al. Quality-of-life and mortality in hemodialysis patients: roles of race and nutritional status. Clin J Am Soc Nephrol 2011;6:1100-11. [CrossRef]

10. Hobson JA, Pace-Schott EF, Stickgold R. Dreaming and the brain: Toward a cognitive neuroscience of conscious states. In: Pace-Schott EF, Solms M, Blagrove M, Harnad S, editors. Sleep and Dreaming. Cambridge: Cambridge University Press; 2003. p. 1-50. [CrossRef]

11. Schredl M. Do sleep disorders affect the dreaming process? Dream recall and dream content in patients with sleep disorders. Sleep Med Clin 2010;5:193-202. [CrossRef]

12. Ağargün MY, Kara H, Bilici M, Cilli AS, Telci M, Semiz UB. The Van
Dream Anxiety Scale: The Subjective Measure of Dream Anxiety in Nightmare Sufferers. Sleep and Hypnosis 1999;4:204-11.

13. Buysse DJ, Reynolds CF 3rd, Monk TH, Berman SR, Kupfer DJ. The Pittsburgh Sleep Quality Index: a new instrument for psychiatric practice and research. Psychiatry Res 1989;28:193-213.

14. Ağargün MY, Kara H, Anlar Ö. Pittsburg Uyku Kalitesi İndeksi'nin Geçerliği ve Güvenilirliği. Türk Psikiyatri Dergisi 1996;7:107-15.

15. Bastien $\mathrm{CH}$, Vallières $\mathrm{A}$, Morin $\mathrm{CM}$. Validation of the Insomnia Severity Index as an outcome measure for insomnia research. Sleep Med 2001;2:297-307. [CrossRef]

16. Boysan M, Güleç M, Beşiroğlu L, Kalafat T. Uykusuzluk Şiddeti İndeksi'nin Türk örneklemindeki psikometrik özellikleri. Anadolu Psikiyatri Dergisi 2010;11:248-52.

17. Beck AT, Ward CH, Mendelson M, Mock J, Erbaugh J. An inventory for measuring depression. Arch Gen Psychiatry 1961;4:56171. [CrossRef]

18. Hisli N. Beck Depresyon Envanteri'nin geçerliği üzerine bir çalışma. Türk Psikoloji Dergisi 1988;6:118-26.

19. Hisli N. Beck Depresyon Envanteri'nin üniversite öğrencileri için geçerliliği, güvenirliği. Türk Psikoloji Dergisi 1989;7:3-13.

20. Beck AT, Epstein N, Brown G, Steer RA. An inventory for measuring clinical anxiety: psychometric properties. J Consult Clin Psychol 1988;56:893-7. [CrossRef]

21. Ulusoy M. Beck Anksiyete Envanteri: Geçerlik ve güvenirlik çalışması. İstanbul: Bakırköy Ruh ve Sinir Hastalıkları Hastanesi; 1993.

22. Razeghi E, Sahraian MA, Heidari R, Bagherzadeh M. Association of inflammatory biomarkers with sleep disorders in hemodialysis patients. Acta Neurol Belg 2012;112:45-9. [CrossRef]

23. Pinto AR, da Silva NC, Pinato L. Analyses of melatonin, cytokines, and sleep in chronic renal failure. Sleep Breath 2016;20:339-44.

24. Chiang HH, Livneh H, Yen ML, Li TC, Tsai TY. Prevalence and correlates of depression among chronic kidney disease patients in Taiwan. BMC Nephrol 2013;14:78. [CrossRef]

25. Teles F, Azevedo VF, Miranda CT, Miranda MP, Teixeira Mdo C, Elias RM. Depression in hemodialysis patients: the role of dialysis shift. Clinics (Sao Paulo) 2014;69:198-202. [CrossRef]

26. Zalai D, Szeifert L, Novak M. Psychological distress and depression in patients with chronic kidney disease. Semin Dial 2012;25:428-38. [CrossRef]

27. Rajan EJ, Subramanian S. The effect of depression and anxiety on the performance status of end-stage renal disease patients undergoing hemodialysis. Saudi J Kidney Dis Transpl 2016;27:331-4. [CrossRef]

28. Cohen SD, Cukor D, Kimmel PL. Anxiety in Patients Treated with Hemodialysis. Clin J Am Soc Nephrol 2016;11:2250-55. [CrossRef]

29. Liakopoulos V, Stefanidis I, Eleftheriadis T, Musso CG, Ioannidis I, Oreopoulos DG. Age and underdialysis as predictors of sleep disorders in peritoneal dialysis patients. Int Urol Nephrol 2006;38:359-60. [CrossRef] 